\title{
Evaluation of Cytotoxicity and Biological Activities in Extracellular Polysaccharides Released by Cyanobacterium Arthrospira platensis
}

\author{
Rafika Challouf*, Lamia Trabelsi, Rym Ben Dhieb, Omeya El Abed, Ali Yahia, Khamissa \\ Ghozzi, Jihen Ben Ammar, Hela Omran and Hatem Ben Ouada \\ Laboratoire de Biodiversité et Biotechnologie Marine; Institut National des Sciences et Technologies de la Mer; BP \\ 59; 5000; Monastir - Tunisia
}

\begin{abstract}
The aim of this work was to evaluate the cytotoxicity of Arthrospira platensis Extracellular Polymeric Substances (EPS) for colon cancer and kidney cell lines. Results showed that EPS were free from cytotoxic effects. A variety of solvents were assessed for their ability to extract the bioactive ingredients from EPS. Methanol gave the highest yield $(75.75 \%)$ than other solvents. The extracts were tested for activities against a collection of Gram+/- bacteria. The methanol extract exhibited a more potent activity than the other organic extracts, whereas the aqueous extract was active against Staphylococcus epidermis (Gram+) and Salmonella typhimurium (Gram-). Finally, The extracts were also tested for the antioxidant activity, using the Trolox Equivalent Antioxidant Activity assay. The methanol extract displayed a moderate antioxidant activity $($ TEAC $=0.027 \mathrm{mg} / \mathrm{ml})$. The HPLC analysis of this extract revealed two distinct peaks: $8.1 \mathrm{kDa}(8.31 \mathrm{~min})$ and $4.1 \mathrm{kDa}(8.54 \mathrm{~min})$.
\end{abstract}

Key words: Cyanobacteria, Exoplysaccharides, cytotoxicity, antibacterial, antioxidant, activity

\section{INTRODUCTION}

Cyanobacteria (blue-green algae) are known to produce intracellular and extracellular metabolites with diverse biological activities such as antibacterial (Falch et al., 1995; Mundt et al., 2001), antifungal (MacMillan et al., 2002), cytotoxic (Luesch et al., 2000), algaecide (Papke et al., 1997), immunosuppressive (Koehn et al., 1992) and antiviral (Koehn et al., 1992). Although most of the bioactive metabolites that have been isolated from cyanobacteria were accumulated in the biomass, these microorganisms are also known to excrete various biological active compounds during their growth (Jaki et al., 1999; 2000; 2001). Copious amounts of these Extracellular Polymeric Substances (EPS) are excreted in the forms of sheaths, slimes or capsules, but very little is known about their diversity, mode of synthesis, structure or proprieties (Morvan et al., 1997).

Cyanobacterial EPS (polysaccharidic in nature) present a set of unique biochemical properties that make them interesting from the biotechnological point of view. These complex exopolysaccharides are composed of at least 10 different monosaccharides and are characterized by the presence of pentoses (usually absent in polysaccharides of prokaryotic origin), as well as

*Author for correspondence: rafikach@yahoo.fr 
their anionic nature due to the presence of acidic sugars (glucuronic and/or galacturonic acids) and anionic organic (acetyl, pyruvil) and inorganic (phosphate and sulphate) substituents. Besides the standard applications of cyanobacterial EPS as food coating, emulsifying and gelling agents, flocculants and hydrating agents, their anionic nature makes them interesting for biomedical applications. In the field of bioremediation, EPS are used to remove the toxic metals from the polluted waters (Otero and Vincenzini, 2003).

Arthrospira platensis, previously known as Spirulina platensis, is a cyanobacterium characterized by the high levels of proteins, vitamins, minerals, polyunsaturated fatty acids, zeaxanthin and myxoxanthophyll (Li et al., 2003; Morist et al., 2001). A. platensis EPS are very rich polymers that contain a variety of macromolecules, which make them valuable for use in the pharmaceutical industry. Benedetti et al. (1989) reported that A. platensis EPS contained sulphate groups and uronic acids and, thus, displayed a non-Newtonian, pseudoplastic behaviour that could be useful in industrial applications. The same authors demonstrated that the sulphated A. platensis EPS had a wide range of important biological properties, such as the ability to act as anticoagulants and interfere with the adsorption and penetration of some enveloped viruses. Kaji et al. (2004) reported antiatherogenic and anti-thromobogenic activities in A. platensis EPS. A. platensis has been also studied for its antiviral properties (Hayashi et al., 1993; Ayehunie et al., 1998), which seem to be related to its sulfated polysaccharide, named calcium spirulan (Ca-SP) (Hayashi et al., 1996a,b). Sodium spirulan (Na-SP) was another sulfated polysaccharide, isolated from A. platensis, exhibiting antithrombin activity by the activation of heparin cofactor II (Hayakawa et al., 2000). In addition, Na-SP influences the functions of vascular endothelial cells such as proliferation (Kaji et al., 2002a), repair after wounding (Kaji et al., 2002b) and metabolism of proteoglycans (Kaji et al., 2002c). However, much work is still required to elucidate the structure of EPS in $A$. platensis and its relationship with their function.

The various laboratory methods used to prepare the EPS, such as water extraction, ethanol extraction, acid hydrolysis, and enzymatic hydrolysis, generate different products with different activities, due to the fact that polymersolvent interactions dictate the conformation of the dissolved polymer (Basedow et al., 1980). Hence, the objective of the present study was to screen for a set of biological proprieties, namely cytotoxicity, as well as antibacterial and antioxidant activities, through the analysis of aqueous and organic solvent extracts obtained from the EPS of $A$. platensis.

\section{MATERIALS AND METHODS}

Cyanobacterium strain, culture conditions and EPS purification and characterization

The A. platensis strain "Compére 1968/3786" was used in this study. The strain was kindly provided by the Botany Department of Liege University, Belgium. After 25 days of culture, following the protocol described in Trabelsi et al. (2009), the $A$. platensis strain, at the stationary phase, was filtered through Millipore filters with a $25 \mu \mathrm{m}$ pore diameter. The resulting supernatant was filtered again through a Whatman filter paper no. 2 (Whatman International Ltd., UK) to separate the culture medium from the cells. The resulting filtrate, which contained the culture medium and the released EPS was concentrated using a tangential ultrafiltration cell using a $30 \mathrm{Kda}$ pore size membrane (Millipore, USA). The membranes were washed three times with deionised water to eliminate the low molecular weight substances. Finally, the purified EPS were freeze-dried and weighed. This crude EPS was characterized for its protein, neutral sugar, and uronic acid contents by colorimetric analyses and for its carbon, hydrogen, nitrogen and sulphur content by elemental analysis following the method of Trabelsi et al. (2009).

\section{Cytotoxicity evaluation}

The cytotoxicity of EPS was evaluated for colon cancer cell lines "Caco-2" and kidney cell lines "Vero" from green monkey kidney (Biovalori, France), using the MTT assay. Caco-2 cells were maintained in Earle's Minimum Essential Medium (Sigma, USA), supplemented with $10 \%$ foetal calf serum (Biosera, U.K.), 2 M L-glutamine (Sigma, USA), $1 \%$ non-essential amino acids (Sigma, USA), $100 \mathrm{IU} / \mathrm{ml}$ penicillin and $100 \mu \mathrm{g} / \mathrm{ml}$ streptomycin (Sigma, USA). Vero cells were incubated in humidified air: $\mathrm{CO}_{2}(95: 5)$ mixture at $37^{\circ} \mathrm{C}$. Cells were grown in RPMI 1640 medium (Sigma, USA) supplemented with $10 \%$ foetal calf serum, $1 \%$ L-glutamine $(200 \mathrm{mM})$ and a $1 \%$ mixture of penicillin $(100 \mathrm{IU} / \mathrm{ml})$ and streptomycin 
(100 $\mu \mathrm{g} / \mathrm{ml}$ ). MTT assay (Mosman, 1983) was repeated three times for each EPS concentration, by seeding cells in 96-well culture plates (Polylabo, France) at the rate of $2.10^{4}$ cells/well and treated with increasing concentrations of EPS $(0,100,200,300$ and $400 \mu \mathrm{g} / \mathrm{ml})$ for $24 \mathrm{~h}$. The MTT solution $(150 \mu \mathrm{l}, 5 \mathrm{mg} / \mathrm{ml})$ dissolved in the culture medium was added to the culture wells and the plates were incubated at $37^{\circ} \mathrm{C}$ for $3 \mathrm{~h}$. Supernatant was removed and $200 \mu \mathrm{l}$ of isopropanol were added to each well before reading the optical density at $540 \mathrm{~nm}$ with an ELISA-reader (Stat Fax 3200, Awareness Technology, USA). Dose-response curves were computer plotted after converting the mean data values to percentages of the control response. Cultures were incubated with EPS for 24h and the dose of EPS which gave 50\% inhibition of live cells (IC50) was derived from the plotted data by linear extrapolation. The data were expressed as mean \pm standard deviation (SD) from at least three independent determinations (triplicates) for each experimental point.

\section{Preparation of EPS extracts for antioxidant and antibacterial assays}

The methanol, hexane, petroleum ether, ethanol, acetone and water-soluble EPS fractions were prepared by mixing the lyophilized EPS with the corresponding solvent during $30 \mathrm{~min}$ (ratio 40: 10 $\mathrm{mg} / \mathrm{ml}$ ). The mixture was centrifuged (4000rpm, $20 \mathrm{~min}, 4^{\circ} \mathrm{C}$ ) and the obtained residues were transferred back into extraction flask, mixed with $10 \mathrm{ml}$ of the appropriate solvent and the procedure repeated twice. After the extraction, the EPS were concentrated using either a Rotavapor RE100 (Bibby Scientific Stuart, France) for organic solvent-soluble EPS, or a freeze dryer (Telstor Lyoalfa 6, Spain) for water-soluble EPS. The concentrated EPS were weighed and new extract solutions were prepared for subsequent bioassays by adding $2 \mathrm{ml}$ of a $10 \%$ dimethyl sulfoxide (DMSO) aqueous solution for the antibacterial bioassay and by adding $2 \mathrm{ml}$ of the same solvent (as used during the extraction) for the antioxidant assay. All the extracts were preserved at $4^{\circ} \mathrm{C}$. For each solvent used, extraction yield was determined as the percentage of extracted EPS to total EPS content [Extraction yield $(\%)=($ mass of extracted EPS / mass of total EPS) x 100].

\section{Antibacterial assay}

The antibacterial activity of different extracts of the EPS (Methanol, Hexane, Petroleum ether, Ethanol, Acetone, and Water) was assayed qualitatively by the paper disk agar diffusion method, then quantitatively by the determination of Minimum Inhibitory Concentrations (MIC) and Minimum Bactericidal Concentrations (MBC).For the paper disk agar diffusion method, the Grampositive bacterial strains, Micrococcus luteus NCIMB8166, Staphylococcus aureus ATCC25923 and Staphylococcus epidermis NCIMB885 and the Gram-negative bacteria Pseudomonas aeruginosa ATCC27853, Escherchia coli ATCC25922 and Salmonella typhimurium LT2 were used as test organisms. All the microorganisms were kindly provided by the "Laboratoire d'Analyse et de Contrôle des Polluants Chimiques et Microbiologiques de l'Environnement" (Faculty of Pharmacy of Monastir, Tunisia). These microorganisms were maintained on MullerHinton $(\mathrm{MH})$ agar. Inocula were prepared by diluting the overnight cultures $\left(37^{\circ} \mathrm{C}\right.$ for $\left.24 \mathrm{~h}\right)$ in MH Broth medium to approximately $10^{6} \mathrm{cfu} / \mathrm{ml}$. An absorbent disk (Watmann disk no. 3; $6 \mathrm{~mm}$ diameter), impregnated with $20 \mu \mathrm{l}$ of each extract, was dried under laminar air flow and placed on an MH agar plate readily inoculated with the test microorganisms. For each extract, the experiment was performed in triplicate. The plates were incubated at $37^{\circ} \mathrm{C}$ for $18-24 \mathrm{~h}$. A positive control disk of Kanamycine $\mathrm{K} 30$ (1mg/disk) and a negative control with a $10 \%$ DMSO aqueous solution were included in each assay. The extracts containing the antibacterial components produced distinct, clear, circular zones of inhibition around the disks. The diameters of those zones were recorded and used as an indicator of antibacterial activity as described by Ghasemi et al. (2004).

For the quantitative evaluation of antibacterial activity by MIC and MBC, the inocula of bacterial strains were prepared as described above to a final density of $10^{6} \mathrm{cfu} / \mathrm{ml}$. For each extract, a range of concentrations $(0-12 \mathrm{mg} / \mathrm{ml})$ was prepared. Ninety six - microwell plates were prepared by dispensing $165 \mu \mathrm{l}$ of $\mathrm{MH}$ culture broth, $5 \mu \mathrm{l}$ of bacterial inoculum and $30 \mu \mathrm{l}$ of each extract dilution into each well. A negative control with $10 \%$ DMSO was used to ensure that DMSO did not affect the growth. The plates were incubated at $37^{\circ} \mathrm{C}$ for 
$24 \mathrm{~h}$. The MIC was defined as the lowest concentration of the extract, at which the tested microorganism does not display visible growth, as indicated by turbidity (NCCLS, 1999). To determine the MBC, $10 \mu \mathrm{l}$ broth were taken from each well, inoculated in $\mathrm{MH}$ agar and incubated at $37^{\circ} \mathrm{C}$ for $24 \mathrm{~h}$. The $\mathrm{MBC}$ was defined as the lowest concentration of the extract at which $99.99 \%$ or more of the initial inoculum was killed (NCCLS, 1999). The number of surviving microorganisms was determined by the direct count.

\section{Antioxidant assay}

The antioxidant capacities of organic solvent- and water-soluble fractions were evaluated using the Trolox equivalent antioxidant activity (TEAC) method (Re et al., 1998), which measured the ability of a compound to scavenge ABTS. ${ }^{+}$radical.

\section{Purification of active compounds}

High Performance Liquid Chromatography (HPLC) was used for the determination of the average molecular weight of methnolic EPS extract. The column used was a PL-Aquaged OH50 column $(8 \mu \mathrm{m}$ 300x7.5 mm, Agilent Technologies, USA). The calibration was done by analyzing the commercial polysterene sulphonate standards (Chrompack, Netherlands) of different molar masses. The injection volume was $200 \mu \mathrm{l}$ and the temperature was set at $30^{\circ} \mathrm{C}$. An isocratic eluent, a mixtre of $90 \% 0.01 \mathrm{M} \mathrm{NaH} \mathrm{NO}_{4}, 0.1 \mathrm{M}$ $\mathrm{NaNO}_{3}(\mathrm{pH} 7.0)$ and $10 \%$ methanol was used at a flow rate of $1 \mathrm{ml} / \mathrm{min}$. The detector used to identify and quantify the fractions was a DAD operating detector set at $254 \mathrm{~nm}$.

\section{RESULTS AND DISCUSSION}

\section{Cytotoxicity test}

The in vitro cytotoxicity against colon cancer cell lines Caco-2 and kidney Cell lines Vero was expressed by the percentage of cell viability after 24h exposure to each EPS concentration (Fig. 1). Only small differences between the negative control $(0 \mu \mathrm{g} / \mathrm{ml}$ EPS $)$ and samples were detected in the cell viability of the two cells lines. Even when exposed to $400 \mu \mathrm{g} / \mathrm{ml}$ of EPS, the viability of Vero cells and that of Caco-2 cells were not reduced. Since many bioactive molecules used in food (i. e. butylated hydroxyanisole and butylated hydroxytoluene) have been demonstrated to be cytotoxic (Valentao et al., 2002), the current attention is on non-toxic food components. According to the present results, algal EPS purified from $A$. platensis were free from the cytotoxic effects and could be of importance in food industry.

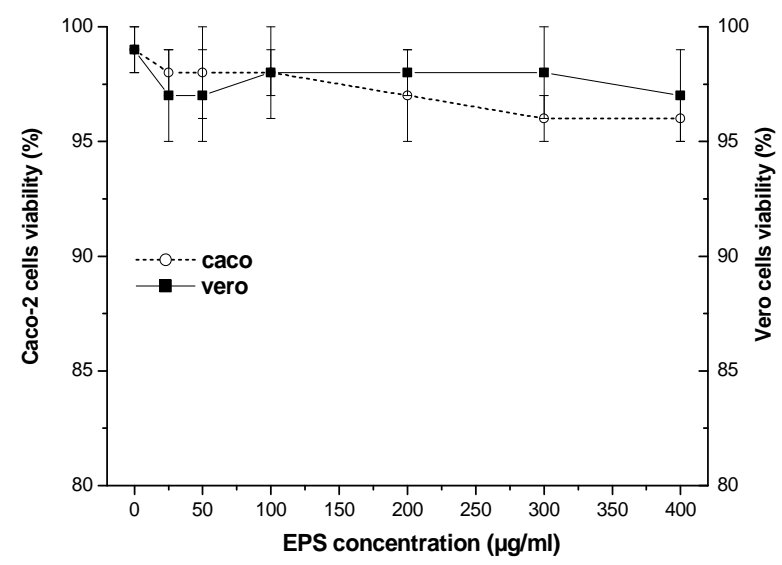

Figure 1 - Percentage ( \pm Standard Deviation) of viability of cultivated Caco-2 and Vero cells, incubated for $24 \mathrm{~h}$ in the presence of EPS at different concentrations determined by MTT assay.

\section{Extraction yield}

Different extracting solvents were tested in order to obtain a large variety of extracts and evaluate the influence of solvent on the ability to extract the natural bioactive ingredients from the EPS excreted by A. platensis. Using methanol, the yield $(75.75 \%)$ was highest which was $21.25 \%$ for ethanol, $13.75 \%$ for hexane, 12.75 for acetone, 
$7.75 \%$ for water and $5.75 \%$ for petroleum ether) under identical conditions. Since the used solvents were characterized by their different polarities (dielectric constant equal to 1.9 for hexane, 4.3 for petroleum ether, 24.3 for ethanol, 33 for methanol and 78.5 for water), the variations in the yields could be probably due to the presence of compounds in the EPS, with different affinities to the solvents. The presence of a wide variety of chemical ingredients within the cyanobacterial EPS has been reported by several authors (Bertocchi et al., 1990; Parikh and Madamwar, 2006; Trabelsi et al., 2009).

\section{Antibacterial assay}

Results of the paper disk agar diffusion assay for the different extracts of EPS are presented in Table 1. The tested extracts exhibited different levels of antibacterial activity against the used microorganism strains. While water and methanol extracts exhibited antimicrobial activity on both Gram-positive and Gram-negative organisms, the ethanol, acetone, petroleum ether and hexane extracts did not exhibit any antimicrobial activity. Furthermore, the methanolic extract showed the broadest activity spectrum, as effective inhibition was recorded against three microbial strains, namely $P$. aeruginosa, $S$. typhimurium and $M$. luteus. However, aqueous extract was active only against two strains, $S$. epidermis and $S$. typhimurium. This variation in term of antimicrobial activities showed the presence of a wide variety of chemical components within $A$. platensis EPS, differing by their affinities to the solvents employed.

Results of the MIC and MBC assays are illustrated in Table 2. The aqueous extract exhibited a direct bactericidal effect against both $S$. epidermis and $S$. typhimurium, as shown by the quotient MBC/MIC $(\leq 4)$. The methanolic extract displayed similar activities against $S$. typhimurium and $P$. aeruginosa, indicating a direct bactericidal action (MBC=MIC); whereas its anti- $M$. luteus activity was different only in term of MIC indicating a rather bacteriostatic effect against $M$. luteus (MBC/MIC>4).

Table 1 - Antibacterial activity levels of different extracts of EPS, from A. platensis.

\begin{tabular}{|c|c|c|c|c|c|c|c|}
\hline & & \multicolumn{6}{|c|}{ Mean diameter of inhibition zone $\pm \mathrm{SD}^{*}(\mathrm{~mm}) /$ Microorganism strain } \\
\hline & & $\begin{array}{c}\text { Micrococcus } \\
\text { luteus } \\
\text { NCIMB } 8166\end{array}$ & $\begin{array}{c}\text { Staphylococ } \\
\text { cus aureus } \\
\text { ATCC } 25923\end{array}$ & $\begin{array}{c}\text { Staphylococc } \\
\text { us epidermis } \\
\text { NCIMB885 }\end{array}$ & $\begin{array}{c}\text { Escherchia } \\
\text { coli } \\
\text { ATCC } 25922\end{array}$ & $\begin{array}{c}\text { Salmonella } \\
\text { typhimurium } \\
\text { LT2 }\end{array}$ & $\begin{array}{l}\text { Pseudomona } \\
\text { s aeruginosa } \\
\text { ATCC } 27853\end{array}$ \\
\hline \multirow{8}{*}{ 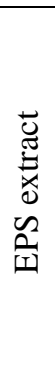 } & Water & - $^{* *}$ & - & $14 \pm 1.4$ & - & $7 \pm 0$ & - \\
\hline & Methanol & $7.5 \pm 0,7$ & - & - & - & $11 \pm 1.4$ & $19.5 \pm 0.7$ \\
\hline & Ethanol & - & - & - & - & - & - \\
\hline & Acetone & - & - & - & - & - & - \\
\hline & Petroleum & & & & & & \\
\hline & Ether & - & - & - & - & - & - \\
\hline & Hexane & - & - & - & - & - & - \\
\hline & $\begin{array}{l}\text { Positive } \\
\text { control }^{* * * *}\end{array}$ & $34.9 \pm 0.14$ & $35.5 \pm 0.7$ & $29.7 \pm 0.2$ & $34.5 \pm 0.7$ & $30.1 \pm 0.14$ & $12.5 \pm 0.7$ \\
\hline
\end{tabular}

Table 2 - Minimum Inhibitory Concentrations (MIC) and Minimum Bactericidal Concentrations (MBC) of active EPS extracts.

\begin{tabular}{|c|c|c|c|c|c|c|}
\hline & & & \multicolumn{4}{|c|}{ Microorganism strains } \\
\hline & & & $\begin{array}{c}\text { Staphylococcus } \\
\text { epidermis } \\
\text { NCIMB } 885\end{array}$ & $\begin{array}{c}\text { Salmonella } \\
\text { typhimurium } \\
\text { LT2 }\end{array}$ & $\begin{array}{c}\text { Pseudomonas } \\
\text { aeruginosa } \\
\text { ATCC } 27853\end{array}$ & $\begin{array}{c}\text { Micrococcus } \\
\text { luteus } \\
\text { NCIMB } 8166\end{array}$ \\
\hline \multirow{4}{*}{ 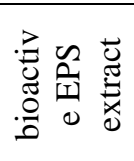 } & \multirow{2}{*}{ Water } & MIC & 5 & 5 & & \\
\hline & & $\mathrm{MBC}$ & 12 & 12 & & \\
\hline & \multirow{2}{*}{ Methanol } & $\mathrm{MIC}$ & & 10 & 10 & 1 \\
\hline & & $\mathrm{MBC}$ & & 10 & 10 & 10 \\
\hline
\end{tabular}

Results are expressed in term of mean concentrations (mg/ml). 


\section{Antioxidant assay}

The Trolox equivalent antioxidant activity (TEAC) method (Re et al., 1998) has been widely applied to evaluate the total antioxidative activity in both lipophilic samples, such as essential oils, and hydrophilic samples, such as polysaccharides $(\mathrm{Li}$ et al., 2006; Leung et al., 2009; Lin et al., 2009). In the present study, results of the TEAC assay for the different EPS extracts (Table 3) clearly indicated that the methanol fraction displayed an inhibition percentage $(45.5 \%)$, which was quite higher than other fractions $(6 \%-26 \%)$, but lesser than that of Trolox $(72.66 \%)$. Based on these results, it could be concluded that only the methanol extract was characterized by a significant antioxidant activity. Therefore, for this extract as well as Trolox, the variation of the inhibition percentage as a function of the concentration using a range of concentrations was studied. This procedure allowed the calculation of the TEAC as $0.027 \mathrm{mg} / \mathrm{ml}$ of Trolox. From these results, it could be inferred that among all the fractions studied; only the methanol presented an antioxidant activity, which, however, remained moderate when compared with the reference solution (Trolox). Free radicals such as superoxide radical $\left(\mathrm{O}_{2}{ }^{\circ}\right)$, hydroxyl radical $\left(\mathrm{OH}^{*}\right)$ and other Reactive Oxygen Species (ROS) are associated with multistage carcinogenesis and mutagenesis. Several polysaccharides have been described to be potent antioxidants and there was a direct relationship between the uronic acid contents and the radical-scavenging effects of $A$. platensis polysaccharide conjugates (Mendiola et al., 2007).

Table 3 - The percentage of ABTS + reduction, for different tested EPS extracts.

\begin{tabular}{ccc} 
& & Inhibition \% \\
\hline Reference solution & Trolox & $72,66 \pm 1,16$ \\
\hline \multirow{2}{*}{ EPS fractions } & Hexane & $2,28 \pm 1.88$ \\
& Acetone & $25,81 \pm 2.81$ \\
& Water & $15,11 \pm 1.25$ \\
& Ethanol & $8,47 \pm 0$ \\
& petroleum ether & $6,35 \pm 0.98$ \\
& Methanol & $45,59 \pm 0.98$ \\
\hline
\end{tabular}

\section{Purification of active compounds}

The HPLC chromatogram of the methanolic polysaccharidic fraction exhibited two distinct peaks at $8.31 \mathrm{~min}$ and $8.54 \mathrm{~min}$, with the MW values corresponding to the peaks as $8.1 \mathrm{kDa}$ (at $8.31 \mathrm{~min}$ ) and $4.1 \mathrm{kDa}$ (at $8.54 \mathrm{~min}$ ) (data not shown). The effect of molecular weight of the polysaccharide on the improvement of the antioxidant potential seemed to be significant. In this context, Chen et al. (2008), studying the antioxidant activities of different polysaccharide fractions from green tea noted that a relatively low molecular weight appeared to increase the antioxidant activity. In addition, Sun et al. (2009) reported that a relatively low molecular weight, together with a high glucuronic acid content might increase the antioxidant activity. Therefore, it could be suggested that the moderate antioxidant potential detected in the methanolic fraction of EPS in the present study would be triggered by the relatively high molecular weight of the active compounds.

Several studies have revealed that the antioxidant activity of polysaccharides are not only dependent on their chemical structure, but also are related to their conformations (Tao et al., 2007), which are highly influenced by the polymer-solvent interactions (Basedow et al., 1980).

\section{ACKNOWLEDGMENTS}

This work is dedicated to the memory of late Pr. Michel BROUERS (Botany Department, Liege University, Belgium). We gratefully acknowledge the Botany Department in Liege University (Belgium) for providing A. platensis strain. We also thank the "Laboratoire d'Analyse et de Contrôle des Polluants Chimiques et Microbiologiques de l'Environnement" (Faculty of Pharmacy of Monastir, Tunisia) for providing bacterial strains used in the antibacterial assays and the "Laboratoire de Recherche sur les Substances Biologiquement Compatibles (Faculty of dental medicine, Monastir, Tunisia) for the valuable help in conducting the cytotoxicity assay. 


\section{REFERENCES}

Ayehunie, S.; Belay, A.; Baba, T. W. and Ruprecht, R. M. (1998), Inhibition of HIV-1 replication by an aqueous extract of Spirulina platensis (Arthrospira platensis ). Journal of Acquired Immune Deficiency Syndrom and Human Retrovirology, 18, 7-12.

Basedow, A. M.; Elbert K. H. and Feigenbutz, W. (1980), Polymer-solvent interactions: Dextrans in water and DMSO. Die Makromolekulare Chemie, 181, 1071 - 1080.

Bertocchi, C.; Navarini, L.; Attilio, C. and Maurizio, A. (1990), Polysaccharides from Cyanobacteriat. Carbohydrate Polymers, 12, 127-153.

Chen, H.; Zhang, M.; Qu, Z. and Xie, B. (2008), Antioxidant activities of different fractions of polysaccharide conjugates from green tea (Camellia Sinensis). Food Chemistry, 106, 559-563.

Crovisier, J. and Encrenaz, T. (1995), Les Comètes, Témoins de la Naissance du Système Solaire. BelinCNRS Editions. pp 143.

Falch, B. S.; Konig, G. M.; Wright, A. D.; Sticher, O.; Angerhofer, C. K.; Pezzuto, J. M. and Bachmann, H. (1995), Biological activities of cyanobacteria: Evaluation of extracts and pure compounds. Planta Medica, 61, 321-328.

Ghasemi, Y. M.; Yazidi, T.; Shafiee, A.; Amini, A.; Shokravi, S. and Zarrini, G. (2004), Parsiguine, A novel antmicrobial substance from Fischerella ambigua. Pharmacology and Biology, 2, 318-322.

Hayakawa, Y.; Hayashi, T.; Lee, J. B.; Ozawa, T. and Sakuragawa, N. (2000), Activation of heparin cofactor II by calcium spirulan. Journal of Biological Chemistry, 275, 11379-11382.

Hayashi, K.; Hayashi, T. and Kojima, I. (1996a). A natural sulphated polysaccharide, calcium spirulan, isolated from Spirulina platensis: in vitro and ex vivo evaluation of anti-herpes simplex virus and antihuman immunodeficiency virus activities. AIDS Research and Human Retroviruses, 12, 1463-1471.

Hayashi, K.; Hayashi, T. and Morita, N. (1993). An extract from Spirulina platensis is a selective inhibitor of herpes simplex type 1 penetration into HeLa cells. Phytotherapy Research, 7, 76-80.

Hayashi, T.; Hayashi, K.; Maeda, M. and Kojima, I. (1996b), Calcium spirulan, an inhibitor of enveloped virus replication, from a blue-green alga Spirulina platensis. Journal of Natural Products, 59, 83-87.

Jaki, B.; Orjala, J.; Heilmann, J.; Linden, A. and Vogler B, Sticher, O. (2000), Novel Extracellular Diterpenoids with Biological Activity from the Cyanobacterium Nostoc commune. Journal of Natural Products, 63, 339-343.

Jaki, B.; Orjala, J. and Sticher, O. (1999), A novel extracellular diterpenoid with antibacterial activity from the cyanobacterium Nostoc comune. Journal of Natural Products, 62, 502-503.
Jaki, B.; Zerbe, O.; Heilmann, J. and Sticher, O. (2001), Two novel cyclic peptides with antifungal activity from the Cyanobacterium Tolypothrix byssoidea (EAWAG 195). Journal of Natural Products, 63, 154-158.

Kaji, T.; Fujiwara, Y.; Hamada, C.; Yamamoto, C.; Shimada, S.; Lee, J. B. and Hayashi, T. (2002a), Inhibition of cultured bovine aortic endothelial cell proliferation by sodium spirulan, a new sulfated polysaccharide isolated from Spirulina platensis. Planta Medica, 68, 505-509.

Kaji, T.; Fujiwara, Y.; Inomata, Y.; Hamada, C.; Yamamoto, C.; Shimada, S.; Lee, J. B. and Hayashi, T. (2002b), Repair of wounded monolayers of cultured bovine aortic endothelial cells is inhibited by calcium spirulan, a novel sulfated polysaccharide isolated from Spirulina platensis. Life Science, 70, 1841-1848.

Kaji, T.; Okabe, M.; Shimada, S.; Yamamoto, C.; Fujiwara, Y.; Lee, J. B. and Hayashi, T. (2004), Sodium spirulan as a potent inhibitor of arterial smooth muscle cell proliferation in vitro. Life Science, 74, 2431-2439.

Kaji, T.; Shimada, S.; Yamamoto, C.; Fujiwara, Y.; Lee, J. B. and Hayashi, T. (2002c), Inhibition of the association of proteoglycans with cultured vascular endothelial cell layers by calcium and sodium spirulan. Journal of Health Science, 48, 250-255.

Koehn, F. E.; Longley, R. E. and Reed, J. K. (1992), Microcolins A and B, new immunosuppressive peptide from the blue-green alga Lyngbya majuscula. Journal of Natural Products, 55, 613-619

Leung, P. H.; Zhao, S.; Ho, K. P. and Wu, J. Y. (2009). Chemical properties and antioxidant activity of exopolysaccharides from mycelial culture of Cordyceps sinensis fungus Cs-HK1. Food Chemistry, 114, 1251-1256.

Li, X. L.; Zhou, A. and Han, Y. (2006). Anti-oxidation and anti-microorganism activities of purification polysaccharide from Lygodium japonicum in vitro. Carbohydrate Polymers, 66, 34-42.

Li, Z. Y.; Guo, S. Y. and Li, L. (2003), Bioeffect of selenite on the growth of Spirulina platensis and its biotransformation. Bioresource Technology, 89, 171176.

Lin, C. L.; Wang, C. C.; Chang, S. C.; Inbaraj, B. S. and Chen, B. H. (2009). Antioxidative activity of polysaccharide fractions isolated from Lycium barbarum Linnaeus. International Journal of Biological Macromolecules, 45, 146-151.

Luesch, H.; Yoshida, W. Y.; Moore, R. E.; Paul, V. J. and Mooberry, S. L. (2000), Isolation, Structure determination and biological activity of lyngbyabellin A from the marine cyanobacterium Lyngbya majuscula. Journal of Natural Products, 63: 611615. 
MacMillan, J. B.; Ernst-Russell, M. A.; De Ropp, J. S. and Molinski, T. F. (2002), Lobocyclamides A-C, lipopeptides from a cryptic cyanobacterium mat containing Lyngbya confervoides. Journal of Organic Chemistry, 67: 8210-8215.

Mendiola, J. A.; Jaime, L.; Santoyo, S.; Reglero, G.; Cifuentes, A.; Ibanez, E. and Senorans, F. J. (2007), Screening of functional compounds in supercritical fluid extracts from Spirulina platensis. Food Chemistry, 102, 1357-1367.

Morist, A.; Montesinos, J. L.; Cusido, J. A. and Godia, F. (2001), Recovery and treatment of Spirulina platensis cells cultured in a continuous photobioreactor to be used as food. Process Biochemistry, 37, 535-547.

Morvan, H.; Gloaguen, V.; Verbret, L.; Joset, F. and Hoffman, L. (1997), Structure-function investigations on capsular polymers as a necessary step for new biotechnological applications: the case of the cyanobacterium Mastigocladus laminosus. Plant Physiology and Biochemistry, 35, 671-683.

Mosman, T. (1983), Rapid colorimetric assay for cellular growth and survival. Application proliferation and cytotoxicity assays. Journal of Immunology Methods, 65, 55-63.

Mundt, S.; Kreitlow, S.; Nowotny, A. and Effmert, U. (2001). Biological and pharmacological investigation of selected cyanobacteria. International Journal of Hygiene and Environment Health, 203, 327-334.

NCCLS (1999), Performance standards for antimicrobial susceptibility testing National Committee for Clinical Laboratory Standards (NCCLS) M100-S9, Vol. 19. Wayne, PA.

Otero, A. and Vincenzini, M. (2003), Extracellular polysaccharide synthesis by Nostoc strains as affected by $\mathrm{N}$ source and light intensity. Journal of Biotechnology, 102: 143-152.
Papke, U.; Gross, E. M. and Francke, W. (1997), Isolation, identification and determination of the absolute confi guration of fi scherellin B. A new algicide from the fresh water cyanobacterium Fischerella muscicola (Thuret). Tetrahedron Lett, 38, 379-382.

Parikh, A.; Madamwar, D. (2006), Partial characterization of extracellular polysaccharides from cyanobacteria. Bioresource Technology, 97, 18221827.

Re, R.; Pellergrini, N.; Proteggente, A.; Pannala, A.; Yang, M. and Rice-Evans, C. (1998), Antioxidant activity applying and improved ABTS radical cation decolorization assay. Free Radical Biology and Medicine, 26, 1231-1237.

Sun, H. H.; Mao, W. J.; Chen, Y.; Guo, S. D.; Li, H. Y.; Qi, X. H.; Chen, Y. L. and Xu, J. (2009), Chemical characteristics and antioxidant properties of the polysaccharides from marine fungus Penicillium $s p$. F23-2. Carbohydrate Polymers, 78, 117-124.

Tao, Y.; Zhang, L.; Yan, F. and Wu, X. (2007), Chain conformation of waterinsoluble hyperbranched polysaccharide from fungus. Biomacromolecules, $\mathbf{8}$, 2321-2328.

Trabelsi, L.; Msakni, N.; Ben Ouada, H. ; Bacha H. ; Roudesli, S. (2009), Partial Characterization of Extracellular Polysaccharides Produced by Cyanobacterium Arthrospira platensis. Biotechnology and Bioprocess Engineering, 14: 27-31.

Valentao, P.; Fernandes, E.; Carvalho, F.; Andrade, P. B.; Scabra, R. M. and Bastos, M. L. (2002), Antioxidative properties of cardoon (Cynara cardunculus L.) infusion against superoxide radical, hydroxyl radical and hypochlorous acid. Journal of Agriculture and Food Chemistry., 50, 4989-4993. 